\title{
How to predict good days in farming: ethnomathematics study with an ethnomodelling approach
}

\author{
Uba Umbara ${ }^{1,2}$, Wahyudin Wahyudin², Sufyani Prabawanto ${ }^{2}$ \\ ${ }^{1}$ Department of Mathematics Education, STKIP Muhammadiyah Kuningan, Indonesia \\ ${ }^{2}$ Department of Mathematics Education, Universitas Pendidikan Indonesia, Indonesia \\ *Corresponding author: uba.bara@upmk.ac.id
}

ARTICLE INFO

Article history:

Received: 5 September 2020

Revised: 10 January 2021

Accepted: 14 January 2021

Published online: 23 January

2021

Published regularly: January 2021

\section{Keywords:}

Numeracy, predictive ability, ethnomathematics, ethnomodelling

\section{ABSTRACT}

Mathematics cannot be separated from everyday life. The use of mathematical concepts in cultural activities can be studied through the ethnomathematics program. However, ethnomathematics research may not be able to provide noticeable results, especially in constructing mathematical modelling for pedagogical purposes. Ethnomodelling later became one of the concepts introduced as an approach in ethnomathematics research. Based on the cultural aspect, the ability to predict a good day in farming is included in the holistic concept of culture because it belongs to the knowledge system and belief system (religion) in the universal element of culture. The research was conducted using an ethnomethodological approach and a realist ethnographic design. Based on this, this research was conducted to describe the ability of the Cigugur indigenous people in Kuningan Regency to predict what days are considered good to start farming activities. Data were collected by using observation techniques, in-depth interviews, documentation, and field notes. Data analysis techniques are carried out in stages through content analysis, triangulation, and pattern search. Based on the study of ethnomathematics, research that is able to describe the mathematical ideas and practices of the indigenous Cigugur community can be classified into several fundamental mathematical dimensions including counting, finding, measuring, designing, and explaining. The use of the ethnomodelling approach in research can describe several mathematical concepts used by the concepts of numbers, sets, relations, congruence, modulo, and mathematical modelling.

(C) 2020 Universitas Muhammadiyah Surakarta

\section{Introduction}

Culture and mathematics, as two conceptualities of knowledge, have various similarities and dependencies. Culture is created when groups of people follow the same trend of assigning meaning and beliefs (Gilsdorf, 2012). Mathematics is knowledge from a culture that grows and develops to connect human needs (Knijnik, 1993). One of the similarities between the two conceptualities is their universal value. Culture has universal elements that can be used to justify the characteristic values in a culture. Meanwhile, the universality of mathematics has long been believed to be a particular form that is inherent

To cite this article:

Umbara, U., Wahyudin, W., \& Prabawanto, S. (2021). How to predict good days in farming: ethnomathematics study with an ethnomodelling approach. JRAMathEdu (Journal of Research and Advances in Mathematics Education), 6(1), 71-85. https://doi.org/10.23917/iramathedu.v6i1.12065 
as a definition, postulate, proposition, theorem, lemma, corollary, and conjecture. Historically, the relationship between culture and mathematics illustrates that mathematics is not independent of culture, but the development of the two is synergistic and mutually reinforcing.

Culture can produce mathematics and vice versa so that idioms about the universality of mathematics need to be re-examined if a desire arises not to set aside culture with its forms and systems. Literalist views like this, usually rule out integral parts of mathematical activities. Mathematical activities that involve mathematicians, such as the role of mathematics in decision making, communication, the interaction of internal coherence, and correspondence with physical reality, especially in developing mathematical theories and awareness that most mathematical conclusions loaded with value (Namukasa, 2004). Mathematical activities are related to the nature of mathematics derived by mathematicians of different cultures in developing mathematical concepts (Bishop, 1991).

Historical and contemporary evidence shows that every human culture is motivated not only by utility but also by values such as aesthetics, religion, or charm to develop some form of mathematics (Joseph, 2010). Mathematics is a way of knowing and maintaining existence in the world, so it will be difficult to imagine if our daily life is not supported by basic mathematical concepts such as measurement, calculation, comparison, and location determination (Namukasa, 2004). Culture is produced from a long process by dynamics and symptoms in a society to maintain both individual and groups. Culture is a concept, beliefs, values, and norms adopted by a society that influence its behaviour in responding to life's challenges that come from the natural surroundings (Tumanggor et al., 2010). In a more specific study, cultural values will appear in symbols, slogans, motto, vision and mission, or something that appears to be the primary reference for the motto of an environment or organization (Sudaryat, 2015).

In accordance with ontological studies, mathematics is concerned with human mental activity, while culture is concerned with knowledge, belief, morals, science, love, intention and human taste. Based on the epistemological aspect, mathematics has logical and logical foundations so that it is closely related to rationalism; in this case, rationalists believe mathematics as a priori knowledge. On the other hand, the empiricists emphasize the role of experience in gaining knowledge (aposteriori). Empiricists view mathematical ideas obtain from experience. Something is interesting that empiricists and rationalists can explain about the new use of mathematics in science, namely regarding the applicability of mathematics to the physical world (Kartasasmita \& Wahyudin, 2014). In this context, the empiricist can explain better, that is, according to the empiricists, mathematical ideas are obtained from the properties of visible objects, and mathematicians examine the relations between these ideas.

The condition means that empiricists perceive that mathematicians indirectly study certain physical relations among visible physical objects. This explanation cannot be given by rationalists, for the problem is that they must show how mathematical entities are. The mathematical entity in question is a mathematical entity that is immutable and is understood to be naturally associated with the objects we see in the world around us and the study of science. Both rationalists and empiricists view mathematics in terms of physical quantities or objects that are expanded and experienced empirically (Machmud, 2011). In other words, there are similarity and agreement in the views and philosophical statements of mathematics of rationalists and empiricists (Shapiro, 2000).

Meanwhile, culture tends to be perceived based on empiricism because it relates to the experiences of a cultural community. Humans usually give some meaning or belief to 
the events that happen in their life (Gilsdorf, 2012). However, based on the flow of cultural rationalism, cultural forms can be understood as forms produced by human reason (tend to arise because of the demands of society's needs). The fairness of an idea depends on the mental modification of the observer (Teng, 2016). Nevertheless, unlike mathematics, culture tends to be generated based on a logical foundation that is intuitively created. However, logic is seen as the antithesis of self-whisper, inspiration, and intuition. However, the 'feminine' characteristic of intuition is a priori, it makes sense to think that intuition must have been necessary and fundamental as a basis or stimulus for logical thinking, or the creation of logic, and mathematics (Wahyudin, 2018). Based on what has been explained, mathematics would be emphasized, created from rationality. It is taken up culturally as an absolute fact.

The similarity of culture and mathematics based on philosophical views from ontological and epistemological aspects provides an opportunity for the study of culture based on mathematical aspects. The study of the two can be an exciting thing to study because there are slices between the two. Mathematics originates from various cultures and can be a source of inspiration for students from their own cultures (Lesser, 2006). In another view, it is stated that mathematics is the knowledge of a human culture that continues to grow and develop to meet their needs (Knijnik, 1993). The values of mathematics are related to the nature of mathematics which is passed down by mathematicians from different cultures in developing mathematics (Bishop, 1999).

Ramaley (as cited in Wijaya, 2012) said that the goal of mathematics education is broader and not bound by the state context put forward by Plato and Socrates, which positions education to guide humans in uncovering the natural laws, truth, and beauty that underlie human life. A review of human development, especially in the fields of science, shows that mathematics is involved in many human efforts to acquire knowledge (Wahyudin, 2013). The explanation regarding the relationship between culture and society is a consideration for researchers in conducting studies on cultural and mathematical values. Integrally cultural values and mathematics have been known as ethnomathematics.

Critical thinking about ethnomathematics is based on two conceptualities of mathematics and culture as a result of human thought and information processing in individual cognitive structures. They are carried out to meet their needs, especially in their social interactions. Anderson (as cited in Fouze \& Amit, 2018) stated that ethnomathematics is developed by cultural groups and serve their genuine interests that derive from their social situations. Ethnomathematics studies seek to follow anthropological studies and try to identify mathematical problems starting from other knowledge in their form and rational (Domite, 2004).

The initial conclusion can be explained that mathematics can develop and develop from various forms of culture. In the case of mathematics, cultures have created ways of interpreting and expressing it that are very different from what we are accustomed to (Gilsdorf, 2012). This conceptual framework encourages several studies on the evolution of mathematical concepts in culture and anthropology by creating bridges between anthropologists, cultural historians, and mathematicians to recognize the different ways of thinking that lead to various forms of mathematics, known as ethnomathematics (D'Ambrosio, 1985). Ethnomathematics, as a research genre in mathematics and mathematics education, has attracted the interest of researchers to explore mathematical concepts that are practised in various groups of society.

Based on the previous research, it is suspected that there are several ideas, processes, symbols, and artefacts that involve mathematical activities in the daily life of the Cigugur indigenous community (Umbara et al., 2019). The results of the ethnomathematics study in 
the Cigugur indigenous community can enrich the previous ethnomathematics study. It was carried out in agricultural activities. The Cigugur indigenous people have practised mathematics, especially in determining good days for planting rice (Umbara et al., $\underline{2019}$ ). Other research on the exploration of the weaving process of the Baduy community in Banten Province in Indonesia states that the Baduy community uses the competency to measure, compare, add, subtract, multiply, and divide even though they have never studied in a traditional school (Turmudi et al., 2016). The other research also discusses the use of the Aboge calendar in determining the holidays at the Kasepuhan palace in Cirebon, West Java Province, Indonesia (Syahrin et al., 2016).

Practically these studies can reveal practices in the form of ethnomathematics that are different from one another, both in one group and in different groups of people. The previous ethnomathematics research in Portugal reveals that there is a lot of thinking and mathematical work behind the actions and discourses of many people and even behind all kinds of products of human activity (Palhares, 2012). However, research on ethnomathematics practice may not be able to provide noticeable results, especially in constructing mathematical modelling for pedagogical purposes.

Ideas on how to construct mathematical modelling for pedagogical purposes are then abstracted and contrasted in a project called "Trilha de Matemática de Ouro Preto" which aims to develop a program called "O Museu Aberto" (Rosa \& Orey, 2013b). Based on the experience from the project, the term ethnomodelling was introduced. It examines the practice of ethnomathematics, especially in involving mathematical formulas that are developed and used in everyday life in a group of people (Rosa \& Orey, 2013b). Ethnomodelling as a methodological approach can be said to be the development of a field of study in ethnomathematics-based research. Ethnomodelling is intended as an evolution so that the mathematical practices and activities of a group of people can be studied comprehensively and are no longer limiting. This restrictive nature will naturally be eroded by the ethnomodelling approach. As an approach, ethnomodelling can allegedly produce studies that highlight aspects of a pedagogical approach. The resulting pedagogical approach is the result of the formulation and abstraction of the process. Ethnomodelling is a process of describing problems and questions that grow from real systems or situations into idealized configurations and versions of mathematics which are formed through critical analysis of the creative production of knowledge, intellectual processes, social mechanisms for institutionalizing academic knowledge, and educational transmission (Rosa \& Orey, 2011).

Aspects of cultural anthropology, mathematical modelling, and ethnomathematics are elements that construct ethnomodelling through a rigorous verification process by highlighting particular values that can confirm real-world mathematical practice with the world of mathematics itself. It can provide the support that mathematics is closely related to everyday life so that it places mathematics in a beneficial context for life. Ethnomodeling procedures involve mathematical practices that are developed and used in various situations of daily life problems faced by members of community groups (Rosa \& Orey, 2012). Ethnomodelling can be defined as knowledge resulting from various mathematical practices used in the culture of a community (Caldeira, 2007). Based on this, the author views this as an exciting study when it can explore the activities of the Cigugur indigenous community, especially concerning its shift from the ethnomathematics concept to the ethnomodelling concept so that it can produce pedagogical aspects for the development of the school mathematics curriculum. The development of a school mathematics curriculum 
in the future is expected to be able to accommodate individual needs through recognition of the role and function of mathematics in everyday life.

This study focuses on the habits of the Cigugur traditional community in calculating the good day which will be used as a reference in carrying out farming activities as a knowledge system that is included in one of the universal elements of culture. Therefore, this research aims to show the activity of the Cigugur indigenous community in numeracy as a unique and exclusive habit. This unique and exclusive habit is a calculation activity that is used to make predictions about an event. Based on this, this research will be guided by the following questions: (1) what are the procedures carried out by indigenous communities in determining good days for farming activities? and (2) What mathematical concepts are used by the indigenous Cigugur community in numeracy activities that can be adopted into mathematics learning in schools?. The success of researchers in conducting ethnomathematics studies with an ethnomodelling approach can reinforce the development of the school mathematics learning curriculum. The practical application of ethnomathematics with the ethnomodelling approach can be used as an effort to recontextualize an approach that focuses on culture-based learning.

\section{Research Methods}

The research approach used in this study is ethnomethodological because it focuses on the method of observing community social activities. The research design used was realist ethnography. The research procedure was carried out with the research subject setting being left naturally (not giving treatment), but the researcher acted as participant observation. Ethnomathematics forms in this study are explored using six fundamental dimensions of universal mathematical activity which consist of: counting, locating, measuring, designing, playing, and explaining (Bishop,1988). Meanwhile, ethnomodelling specifically uses emic, ethical, and dialogical approaches (Rosa \& Orey, 2012). The research was conducted at the Cigugur traditional community in Kuningan Regency. Community activities are centered in the Paseban Tri Panca Tunggal building which is geographically located in Cigugur Village, Kuningan Regency. The Cigugur traditional community is one of the traditional communities that still adhere to customs from generation to generation. The research subjects determined in the study consisted of key informants, main informants, and additional informants. The data collection technique used was to adopt an ethnographic research design by conducting participant observation and in-depth interviews.

Researchers carry out participant observation through direct participation in the situations or settings they observe (Fraenkel et al., 2011). Participant observation is an observation technique carried out through direct participation by researchers in the activities of the Cigugur traditional community. In-depth interviews are the process of obtaining information utilizing face-to-face question and answer between the researcher and the informant through the involvement of the researcher in the informant's life, which is carried out with or without using interview guidelines (Bungin, 2011). Data analysis techniques used in this study consisted of content analysis techniques, triangulation and pattern finding. The content analysis technique serves to present valid data in detail about the culture and habits of the research subjects carried out at the research location. Content analysis is a technique that can be used to study human behaviour indirectly through communication analysis (Cohen et al., 2013). Triangulation techniques can be used to establish the validity of an ethnographer's observations which consists of the process of checking what someone hears and sees by comparing information sources through cross- 
checking information sources. Meanwhile, pattern-setting is a way to check ethnographic reliability to reveal data consistency (Fraenkel et al., 2011). The triangulation technique used is the triangulation of data sources, the content analysis technique uses the symbol coding technique by interpreting the data obtained, while the pattern-finding uses the category creation used in the analysis.

\section{Results and Discussion}

Most of the Cigugur indigenous people work as farmers. Their profession as a farmer cannot be separated from the geographical factors of the natural environment in which they live. This natural condition is alleged to have influenced the civilization of society to form a pattern of thinking, development, and community mentality. In general, agrarian communities use agricultural land to plant rice and secondary crops to meet their daily needs. In this regard, the main characteristic of community economic activities is based on agriculture, namely farming or farming either in the fields or in the garden. People generally consume their agricultural products or sell them to traditional markets. Farming activities that have become daily routines eventually form the habit of the community in doing calculations.

The culture of counting is one of the local geniuses interesting to study. This culture is reflected in a mathematical activity that is one of the oldest human civilizations on earth. Counting is a simple mathematical activity that can never be released in daily activities. The ability to count serves to support other necessary mathematical skills such as grouping, measuring, designing, and explaining. The ability to count has an absolute position in the mathematical activities of society. Counting is often classified as the most straightforward activity, but without having and using numeracy skills, a person will find it difficult to have other mathematical skills that are more complex. The results of research on the community's ability to perform calculations are described in the following sections.

The procedures used by indigenous peoples in determining good days for farming

The results showed that there are unique habits practiced by the community in carrying out calculations to determine the excellent day that will be used to start farming activities. The Cigugur indigenous community uses a calculation formula to determine a good day when starting agricultural activities, namely.

$$
H B B=\frac{N W A K+N P+N B+N T}{5}
$$

*) HBB is the remainder of the division

explanation:

HBB : Hari Baik dalam Bertani / Good Day in Farming

NWAK : Naktu Weton Anggota Keluarga/ Family Member of the day of birth

NP : Naktu Pasaran / the value of five daily cycles

NB : Naktu Bulan / the value of the month

NT : Naktu Tahun / the value of the year

Based on the formula above, there are four parameters used, including the day of birth (naktu weton), the value of five daily cycles (naktu pasaran), the value of the month (naktu bulan), and the value of the year (naktu tahun). Naktu is a value attached to the day, five daily cycles, month, and year. It has been agreed by the community and continues to be used from generation to generation. In general, the value known as naktu has the same 
composition and is used by the Sundanese and Javanese people. Naktu Weton or day of birth is one unit; in other words, every day has a specific of five daily cycles that form a cycle. This cycle is always repeated every day, for example, ahad manis, senen pahing, salasa puhun, rebo wage, kemis kaliwon, jumaah manis, saptu pahing, and so on. To understand the pair between the day cycle and the five daily cycle can be seen in (Umbara et al., 2019). A cycle is a relationship of two consecutive sets. So that we can define, for A is the set of days and B is the set of markets, then we can write A = \{Ahad, Senen, Salasa, Rebo, Kemis, Jumaah, Saptu $\}$ dan B = \{Manis, Pahing, Puhun, Wage, Kaliwon $\}$. More formally, we have definitions, for $\mathrm{A}$ and $\mathrm{B}$ are set. The Cartesian products of $\mathrm{A}$ and $\mathrm{B}$ are sets $\{A X B=(a, b)\} \mid a \in A, b \in B\}$.

As explained earlier, day and the five daily cycle has a specific time or value that is used to perform calculations. The time of day is shown in Table 1.

Table 1

Nilai (naktu) of the day and pasaran

\begin{tabular}{lccc}
\hline \multicolumn{1}{c}{ Name of the day } & Naktu or “Value" & Name of Pasaran & Naktu or "Value" \\
\hline Ahad (as of Sunday) & 5 & Manis & 5 \\
Senen (as of Monday) & 4 & Pahing & 9 \\
Salasa (as of Tuesday) & 3 & Puhun & 7 \\
Rebo (as of Wednesday) & 7 & Wage & 4 \\
Kemis (as of Thursday) & 8 & Kaliwon & 8 \\
Jumaah (as of Friday) & 6 & & \\
Saptu (as of Saturday) & 9 & & \\
\hline
\end{tabular}

Based on Table 1, if someone was born on the day ahad manis, then the value is $5+5$ $=10$. The next parameter used to determine a good day for farming activities is naktu of month and naktu of year. The time of month and year is determined by the rules shown in Table 2.

Table 2

Naktu of month and year

\begin{tabular}{lccc}
\hline \multicolumn{1}{c}{ Name of Month } & Naktu or "Value" & Name of Year & Naktu or "Value" \\
\hline Sura & 7 & Alip & 1 \\
Sapar & 2 & He & 5 \\
Mulud & 3 & Jim Awal & 3 \\
Silih mulud & 5 & Je & 7 \\
Jumadil awal & 6 & Dal & 4 \\
Jumadil akhir & 1 & Be & 2 \\
Rajab & 2 & Wau & 4 \\
Rewah & 4 & Jim Akhir & 3 \\
Puasa & 5 & & \\
Sawal & 7 & & \\
Hapit & 1 & & \\
Rayagung & 3 & & \\
\hline
\end{tabular}

Based on Table 2, it can be understood that there are 12 months in a year, and the year cycle in this calendar repeats every eight years. After each time is known, the next step is to operate this naktu into the previously written formula to find out the remainder of the division result. The residual value from this division is then used to determine the criteria for the day that will be used for farming. The criteria for the days that can be selected are determined based on the criteria shown in Table 3. 
Table 3

Determining the criteria for farming days

\begin{tabular}{lcc}
\hline \multicolumn{1}{c}{ Day criteria } & The remains of division & Meaning \\
\hline Pati & 0 & Death \\
Sri & 1 & Goddess of rice / Prosperity \\
Lungguh & 2 & Good / Position \\
Dunya & 3 & World / Treasure \\
Lara & 4 & Miserable / sick \\
\hline
\end{tabular}

Based on Table 3, there are five day criteria used in determining the day to start farming activities. The concept used by the indigenous Cigugur people is relevant to that of congruence which can be as follows: integers $a$ and integers $b$ are said to be congruent in modulo $n$ if and only if they give the remainder for the same when divided by $n$, where $a, b$, $n \in Z$. It is symbolically represented by $a \equiv b(\bmod n)$. Thus, the mathematical model can be formulated as previously described for each formula resulting from the concept of modulo 5 so that it can be formulated with formulas.

$$
a \equiv c(\bmod n) \text { or } a=5 q+c
$$

This formula can be used to determine the variation in numbers that fall into one of the predefined day criteria. If we determine a is the direction, $\mathrm{c}$ is the remainder of the division, and $q$ is an integer, then for example $b$ is the criteria for days in farming activities, then the criteria for days can be determined as follows.

For number with no remaining division/0 (Pati),

$b \equiv 0(\bmod 5)$ or $b=5 q+0$

The criteria of pati meet the equation:

$b=5 q$

If $q=1$, then $b=5(1) \rightarrow b=5$

If $q=2$, then $b=5(2) \rightarrow b=10$

If $q=3$, then $b=5$ (3) $\rightarrow b=15$

For the remaining division 1 (Sri),

$b \equiv 1(\bmod 5)$ or $b=5 q+1$

The criteria of sri meet the equation:

$b=5 q+1$

If $q=1$, then $b=5(1)+1 \rightarrow b=6$

If $q=2$, then $b=5(2)+1 \rightarrow b=11$

If $q=3$, then $b=5(3)+1 \rightarrow b=16$

For the remaining division 2 (Lungguh),

$b \equiv 2(\bmod 5)$ or $b=5 q+2$

The criteria of lungguh meet the equation:

$b=5 q+2$

If $q=1$, then $b=5$ (1) $+2 \rightarrow b=7$

If $q=2$, then $b=5(2)+2 \rightarrow b=12$

If $q=3$, then $b=5(3)+2 \rightarrow b=17$

For the remaining division 3 (Dunya),

$b \equiv 3(\bmod 5)$ or $b=5 q+3$

The criteria of dunya meet the equation:

$b=5 q+3$

If $q=1$, then $b=5(1)+3 \rightarrow b=8$ 
If $q=2$, then $b=5(2)+3 \rightarrow b=13$

If $q=3$, then $b=5(3)+3 \rightarrow b=18$

For the remaining division 4 (Lara),

$b \equiv 4(\bmod 5)$ or $b=5 q+4$

The criteria of lara meet the equation:

$b=5 q+4$

If $q=1$, then $b=5(1)+4 \rightarrow b=9$

If $q=2$, then $b=5(2)+4 \rightarrow b=14$

If $q=3$, then $b=5(3)+4 \rightarrow b=19$

The dunya criterion is the best day that will be used in carrying out farming activities. However, the criteria for sri and lungguh are sometimes used by the Cigugur Indigenous community. The following is an example of how to determine a good day for farming, for example someone born on a sweet Sunday wants to know whether the month of Rajab in 2020 is an excellent month to be used in farming. Ahad (Sunday) has a naktu of 5, while manis (one of the five daily cycles) has a naktu of 5. The year 2019-2020 (1953 in Sundanese) is called Alip has a naktu of 1, while the month of Rajab (from 25 February 2020 to 25 March 2020) has a naktu 2. After knowing the time of each day, five daily cycles, year, and month, each time is then added up to $5+5+1+2=13$. Then 13 divided by 5 gives the number 2 and the remainder 3 . In words another formula is as follows.

$$
H B B=\frac{5+5+1+2}{5}=\frac{13}{5}=2 \text { remainder } 3 \text {. }
$$

In accordance with Table 3, the remaining number 3 is included in the criteria of dunya. Thus, it can be concluded that people born on ahad manis are suitable if they are going to farm in the month of Rajab in 2020. Apart from the person born on the day ahad manis, people born salasa puhun, jumaah wage, rebo kaliwon, kemis puhun, and jumaah pahing also falls into the criteria of dunya.

The results of the study show that the Cigugur indigenous people use number operations, especially the concept of addition and division after previously using the concept of consecutive pairs and relations. The use of these concepts can be assessed as a dimension of necessary universal mathematical activities: counting, discovering, measuring, designing, and explaining. These activities can be classified into ethnomathematics. When viewed from the universal elements of culture, the numeracy skills practiced by the Cigugur indigenous people can be categorized as a knowledge system in culture.

However, the calculations made by society depend on the beliefs of a person or group of people because it is not a binding rule. Determining a good day is a form of prediction made by the community. The correctness of the forecast/prediction depends on a person's belief in the hope that it does not harm the activities or work to be performed (Suryaatamana et al., 1992). In the correctness of the calculation results, there is hope that the intention or work to be carried out does not miss too far or does not have a negative impact. This hope factor is the cause of the calculation system to determine a good day which can also be categorized as a holistic concept in culture.

The knowledge system related to the capabilities of the Cigugur indigenous people holistically intersects the belief system so that its implementation is not binding or flexible. Most of the people believe and carry out the results of these calculations in several 
activities that will be carried out. In general, the Sundanese are accustomed to doing mathematical calculations, modelling, and predicting phenomena by using symbolic mathematical calculations consisting of basic units, length, width, area, height, weight, group, and time (Abdullah, 2017). The calculation activities carried out are not binding or flexible. It means that counting activities can be carried out or not depending on the beliefs of each individual, but most people believe and carry out the results of these calculations. The cultural activities of the Sundanese people have been carried out from generation to generation, including estimating, pattern making activities, and building geometric patterns (Muhtadi et al., 2017). The activities of estimating, making patterns, and building geometric patterns are the basis for habits that have been carried out from generation to generation.

Epistemologically, this numerical knowledge appears based on intuition. This intuition develops empirically based on the experiences of people in the past. However, this rationalism and empiricism aspects may result differently with the reality that happens and is experienced by a person. Based on the mental ideas and processes carried out, these activities may be categorized as scientific content but based on axiological aspects, unless It will still be debated. Activities such as these become collections of knowledge built up by humans over time and across generations who live and interact with their own historical, social, cultural and natural environments (D'Ambrosio, 1990) whether we realize it or not, that almost all human activities are carried out based on calculations based on the natural conditions in which they live (Maryati \& Prahmana, 2018).

The results of the study reinforce the view that mathematics is believed to be a tool to meet human needs in living everyday life. Practically it has become a general view that mathematics is always concerned with the practical problems of calculating and recording numbers (Kartasasmita \& Wahyudin, 2014) thus helping to explain the nature of mathematics from a cross-cultural, anthropological and political perspective, not philosophical (Powell \& Frankenstein, 1997). It is strong evidence to claim that one of the focuses of ethnomathematics studies is to explore traditional elements in society that are related to the ideas and practices of mathematics practiced by the community.

Ethnomathematics is a scientific system capable of building harmonious and beneficial relationships between humans and between humans and nature (D'Ambrosio, 1999). Ethnomathematics can be used to show how mathematics is produced, transferred, and propagated specifically in various cultural systems (Zhang \& Zhang, 2010) through the principles of mutual respect, solidarity and cooperation with others (D'Ambrosio, 2007). Based on this, it is crucial to understand that critical thinking regarding ethnomathematics is based on the results of thinking, reasoning, and information processing in the human cognitive structure against the conceptuality of mathematics and culture (Umbara et al., $\underline{2019})$.

The mathematical concept used by the Cigugur indigenous people in arithmetic that can be adopted in mathematics learning in schools

Through the use of the ethnomodelling approach used in ethnomathematics research, it is known that the community uses the concepts of modulo and congruence. Ethically, the Cigugur community uses a unique formula to determine a good day to start farming. The Cigugur indigenous community uses the day variable, pasaran, month, and year through a symbolization known as time. The activity of determining a good day can be understood as the use of the number rule. The census is an activity that is classified as old in mathematics practice. It is suspected that since 50,000 years ago, humans have carried out the census, based on archaeological evidence (Eves \& Eves, 1964). 
Counting numbers is related to the basic operations of counting, such as addition, multiplication, subtraction, and division. Meanwhile, the census rules include correspondence, permutation, and combination. The activity of calculating good days in the Cigugur traditional community itself is an idea, and mathematical practice carried out by the Cigugur traditional community, included in inclusive counting/enumeration. Inclusive enumeration is usually done by the community in counting the days on the calendar. The concept of counting numbers used by the Cigugur indigenous community consists of addition, division and comparison operations. The concept of addition and division can be found based on the formula previously described. The community varies the addition between the time of day, market time, month time, and year time. Next, they divide to get the remainder of the division. The concept of comparison is then used to compare the remainder of the division result with predetermined criteria. In other words, the quantitative and qualitative aspects of the evaluation are used by the Cigugur indigenous community to determine a good day. Comparisons were made when they took measurement and day judgment based on predetermined standard sizes. It fits the dimensions of necessary universal mathematical activities, such as counting, placing, and explaining.

Based on this study, the Cigugur indigenous people understand the use of the concept of enumeration in determining a good day. Through the use of a standard formula in determining good days, the Cigugur traditional community uses symbols which are termed the time for each day, market, month and year. The numbers are placed according to standard rules with a predetermined time and the formulation of the number operation. They calculate each value according to specific formulas in different activities to produce the remainder of the division and explain the types of good days according to predetermined standard criteria. Researchers say that there were no mistakes made by the Cigugur indigenous community in carrying out the enumeration operations, but they could not use a more straightforward formula in determining the days according to the predetermined criteria.

In this regard, ethically, the researcher justifies that some of the mathematical concepts used are by the concepts of numbers, sets, relations, congruence, and modulo operations. Based on the dialectical approach, researchers make mathematical modelling based on the concepts of modulo and congruence. We develop mathematical modelling to make it easier for people to determine criteria directly in finding a fortune that will be used by the community. Based on this, it can be understood that dialectics serves to bridge the dialogue between ethics and emics taken from the realities of different cultural groups into academic mathematics (Rosa \& Orey, 2012). The results showed that the ethnomathematics study using the ethnomathematics approach could produce more comprehensive research. It can also improve the performance of ethnomathematics research, primarily, in the aspect of mathematical modelling that was produced to help facilitate abstracting mathematical concepts.

The results of this study provide an understanding that mathematics practices carried out by the community are carried out by promoting reasoning and logic. Intuition elements and the real context they face are the main elements in the dialogue and elaboration of mathematical modelling carried out by researchers. It is important for researchers to continue investigating ethnomodelling in the context of non-Western cultures and to consider applying new views to old themes. Ethnomodelling investigations were carried out to broaden the discussion about the possibilities and potentials of ethnomathematics and mathematical modeling. The possibilities and potentials of ethnomathematics, including ethnomathematical perspectives and mathematical modeling that value socio- 
cultural diversity to understand differences through dialogue and respect (Rosa \& Orey, 2013a). Ethnomodelling can provide consideration in a variety of processes that aids in the building and development of cultural scientific and mathematical knowledge.

Based on the mathematical concepts used by the Cigugur indigenous people in numeracy activities previously reviewed, there is an opportunity to adopt academic mathematics concepts that can be adopted into mathematics learning in schools. Among the concepts of academic mathematics that can be adopted into mathematics learning in schools include the concepts of numbers, sets, relations, congruence, modulo, and mathematical modeling which can be implemented simultaneously.

\section{Conclusion}

The application of mathematical ideas, procedures, and concepts used in the social life of the Cigugur indigenous people can be categorized into knowledge systems. The knowledge system is one of the seven universal elements of culture. The knowledge system in society deserves to be called one of the local geniuses who exist, grow and develop in society. In this study, the knowledge system fulfils the holistic principle in understanding cultural elements because it intersects with the religious system (belief). The study of the ethnomathematics program was able to describe the mathematical ideas and practices of the Cigugur indigenous peoples. The Cigugur traditional community carries out the activity of calculating good days using a standard formula consisting of coding, addition, and division. Fundamental dimensions of mathematics can be classified into counting, searching, measuring, designing, and explaining.

The ethnomodelling approach can illustrate some of the mathematical concepts used by the Cigugur indigenous community. The concepts of academic mathematics used include numbers, sets, relations, congruence, modulo, and mathematical modelling. The two reviews that have been described provide an understanding that the comprehensive ethnomathematics and ethnomodelling studies in this study can be used to bridge communication between aspects of culture, traditional mathematics, and academic mathematics. The results of the analysis show that traditional mathematics content has the opportunity to be integrated into academic mathematics. Academic mathematics concepts can be adopted into mathematics learning in schools, including the concept of numbers, sets, relations, congruence, modulo, and mathematical modelling. Therefore, we hope that culture-based mathematics learning which is carried out simultaneously can be a solution for introducing integrated and culture-based mathematics learning. The concepts of numbers, sets, relations, congruence, modulo, and mathematical modeling can be taught through cultural contextual descriptions so that mechanistic and structural approaches can be avoided in mathematics learning by teachers. Future mathematics learning can be done by maximizing the potential for contextual problems that are close to the environment and student culture.

\section{Acknowledgment}

On this occasion, the author would like to express appreciation and gratitude to the Ministry of Education and Culture and the Ministry of Research and Technology/National Agency for Research and Innovation as scholarship (BPPDN) and grants (Penelitian Disertasi Doktor), as well as all parties who have a significant impact on the success and completion of this research. 


\section{Bibliography}

Abdullah, A. S. (2017). Ethnomathematics in perspective of sundanese culture. Journal on Mathematics Education, 8(1), 1-16. https://doi.org/10.22342/ime.8.1.3877.1-15

Bishop, A. J. (1988). Mathematics education in its cultural context. Educational Studies in Mathematics, 19(2), 179-191. https://doi.org/10.1007/BF00751231

Bishop, A. J. (1991). Mathematical enculturation: A cultural perspective on mathematics education (Vol. 6). Springer Science \& Business Media.

Bishop, A. J. (1999). Mathematics teaching and values education-an intersection in need of research. $Z D M, 31(1), 1-4$. https://doi.org/10.1007/s11858-999-0001-2

Bungin, B. M. (2011). Metodologi Penelitian Kualitatif Aktualisasi Metodologis ke Arah Ragam Varian Kontemporer (8th ed.). RajaGrafindo Persada.

Caldeira, A. D. (2007). Etnomodelagem e suas relações com a educação matemática na infância. Modelagem Matemática Na Educação Matemática Brasileira: Pesquisas e Práticas Educacionais. Recife: SBEM, 81-97.

Cohen, L., Manion, L., \& Morrison, K. (2013). Research methods in education. routledge. https://doi.org/10.4324/9780203720967

D'Ambrosio, U. (1985). Ethnomathematics and its place in the history and pedagogy of mathematics. For the Learning of Mathematics, 5(1), 44-48.

D’Ambrosio, U. (1990). Etnomatemática (Ethnomathematics). São Paulo, SP, Brazil: Editora Ática.

D'Ambrosio, U. (1999). Ethnomathematics and its first international congress. ZDM, 31(2), 50-53. https://doi.org/10.1007/s11858-999-0008-8

D'Ambrosio, U. (2007). Peace, social justice and ethnomathematics. The Montana Mathematics Enthusiast, Monograph, 1(2007), 25-34.

Domite, M. do C. S. (2004). Notes on teacher education: an ethnomathematical perspective (F. Favilli (ed.); pp. 17-28). PISA : Tipografia Editrice Pisana.

Eves, H., \& Eves, J. H. (1964). An introduction to the history of mathematics (Vol. 6). holt, Rinehart and Winston New York.

Fouze, A. Q., \& Amit, M. (2018). Development of mathematical thinking through integration of ethnomathematics folklore game in math instruction. EURASIA Journal of Mathematics, Science and Technology Education, 14(2), 617-630. https://doi.org/10.12973/ejmste/80626

Fraenkel, J. R., Wallen, N. E., \& Hyun, H. H. (2011). How to design and evaluate research in education. New York: McGraw-Hill Humanities/Social Sciences/Languages.

Gilsdorf, T. E. (2012). Introduction to cultural mathematics: With case studies in the Otomies and Incas. John Wiley \& Sons. https://doi.org/10.1002/9781118194164

Joseph, G. G. (2010). The crest of the peacock: Non-European roots of mathematics. Princeton University Press. https://doi.org/10.1515/9781400836369

Kartasasmita, B. G., \& Wahyudin. (2014). Sejarah dan Filsafat Matematika. Universitas Terbuka.

Knijnik, G. (1993). Ethno-Mathematical Approach in Mathematical Education: a Matter of Political Power. For the Learning of Mathematics, 13(2), 23-25.

Lesser, L. M. (2006). Book of numbers: Exploring Jewish mathematics and culture at a Jewish high school. Journal of Mathematics and Culture, 1(1), 8-31.

Machmud, T. (2011). RASIONALISME DAN EMPIRISME Kontribusi dan dampaknya pada perkembangan filsafat matematika. Jurnal Inovasi, $8(01)$.

Maryati, M., \& Prahmana, R. C. I. (2018). Ethnomathematics: exploring the activities of designing kebaya kartini. MaPan: Jurnal Matematika Dan Pembelajaran, 6(1), 11-19. 


\section{https://doi.org/10.24252/mapan.2018v6n1a2}

Muhtadi, D., Sukirwan, Warsito, \& Prahmana, R. C. I. (2017). Sundanese Ethnomathematics: Mathematical Activities in Estimating, Measuring, and Making Patterns. Journal on Mathematics Education, 8(2), 185-198. https://doi.org/10.22342/ime.8.2.4055.185198

Namukasa, I. (2004). School mathematics in the era of globalization. Interchange, 35(2), 209-227. https://doi.org/10.1007/BF02698850

Palhares, P. (2012). Mathematics Education and Ethnomathematics. A Connection in Need of Reinforcement. REDIMAT-Journal of Research in Mathematics Education, 1(1), 7992.

Powell, A. B., \& Frankenstein, M. (1997). Ethnomathematics: Challenging Eurocentrism in mathematics education. State University of New York Press Albany, NY.

Rosa, M., \& Orey, D. C. (2011). Ethnomodeling: a pedagogical action for uncovering ethnomathematical practices. Journal of Mathematical Modelling and Application, 1(3), 58-67.

Rosa, M., \& Orey, D. C. (2012). The field of research in ethnomodeling: emic, ethical and dialectical approaches. Educação e Pesquisa, 38(4), 865-879. https://doi.org/10.1590/S1517-97022012000400006

Rosa, M., \& Orey, D. C. (2013a). Ethnomodeling as a research theoretical framework on ethnomathematics and mathematical modeling. Journal of Urban Mathematics Education, 6(2), 62-80.

Rosa, M., \& Orey, D. C. (2013b). The mathematics of the curves on the wall of the Colégio Arquidiocesano and its mathematical models: a case for ethnomodeling. Journal of Mathematical Modelling and Application, 1(8), 42-62.

Shapiro, S. (2000). Thinking about mathematics: The philosophy of mathematics. OUP Oxford. https://doi.org/10.1093/0195139305.001.0001

Sudaryat, Y. (2015). Wawasan kesundaan. Jurusan Pendidikan Bahasa Daerah, Fakultas Pendidikan Bahasa dan Sastra.

Suryaatamana, E., Darsa, U. A., Erlyane, A., \& Wartini, T. (1992). Paririmbon Sunda (Jawa Barat) (Rosyadi (ed.)). Direktorat Jenderal Kebudayaan.

Syahrin, M. A., Turmudi, \& Puspita, E. (2016). Study ethnomathematics of aboge (alif, rebo, wage) calendar as determinant of the great days of Islam and traditional ceremony in Cirebon Kasepuhan Palace. AIP Conference Proceedings, 1708(1), 60009. https://doi.org/10.1063/1.4941172

Teng, M. B. A. (2016). Rasionalis dan Rasionalisme dalam Perspektif Sejarah. Jurnal Ilmu Budaya, 4(2 Desember). https://doi.org/10.30738/sosio.v2i1.488

Tumanggor, R., Ridho, K., \& Nurochim. (2010). Ilmu Sosial \& Budaya Dasar. Jakarta: Kencana Prenadamedia Group.

Turmudi, Juandi, D., Hidayat, A. S., Puspita, E., \& Ulum, A. S. (2016). Exploring Ethno-Mathematics: How the baduy of indonesia use traditional mathematics skills in weaving. International Journal of Control Theory and Applications, 9(23), 323-339.

Umbara, U., Wahyudin, \& Prabawanto, S. (2019). Ethnomatematics: how does cigugur traditional community use palintangan on farming. Journal of Physics: Conference Series, 1265(1), 12025. https://doi.org/10.1088/1742-6596/1265/1/012025

Wahyudin. (2013). Hakikat, Sejarah dan Filsafat Matematika. Penerbit Mandiri.

Wahyudin, W. (2018). Etnomatematika Dan Pendidikan Matematika Multikultural. Prosiding Seminar Nasional Pendidikan Matematika Etnomatnesia.

Wijaya, A. (2012). Pendidikan matematika realistik: Suatu alternatif pendekatan 
pembelajaran matematika. Yogyakarta: Graha Ilmu.

Zhang, W., \& Zhang, Q. (2010). Ethnomathematics and its integration within the mathematics curriculum. Journal of Mathematics Education, 3(1), 151-157. 